\title{
Protocol for Malignant and Potentially Malignant Neoplasms of the Testis and Paratestis
}

\section{Association of Directors of Anatomic and Surgical Pathology}

I. Gross description-ADASP recommends that the following features be included in the final report because they are generally accepted as being of prognostic importance, required for staging or therapy, and/or traditionally accepted.

A. Number of specimen containers

B. Condition of the specimen-fresh, in formalin, intact, incised by surgeon or pathologist, etc.

C. Identification-patient name, case number, laterality, specimen identification ("labelled as ...")

D. Structures attached to testis-epididymis, spermatic cord, tunica vaginalis, scrotum

E. Dimensions of all of the specimens

F. Tumor description

1. Site in testis/paratestis-central, inferior pole, superior pole, testicular hilum, epididymis, paratesticular soft tissue, spermatic cord, etc.

2. Tumor size, shape, consistency, color, cysts, scar, necrosis, hemorrhage, calcifications

3. Relationship to tunica albuginea

4. Relationship to epididymis and spermatic cord

5. If spermatic cord involvement, distance of tumor to cord margin. It is recommended that sections of the spermatic cord be obtained before incision of the main tumor to avoid contamination (1)

6. Satellite tumors, if present

G. Other lesions of the testis

H. Tissue submitted for special study

II. Diagnostic information

A. Topography-left or right testis

B. Name of operation - as designated by surgeon, e.g., radical or simple orchiectomy

C. Histologic type - a modified classification of the World Health Organization (WHO) (2) is recommended (3)

1. Germ cell tumors

a. Intratubular germ cell neoplasia

i. Unclassified type (IGCNU)

ii. Other forms (specify)

b. Tumors of one histologic type

i. Seminoma

$\alpha$. Variant-seminoma with syncytiotrophoblastic cells (4)

ii. Spermatocytic seminoma

$\alpha$. Variant-spermatocytic seminoma with a sarcomatous component $(5,6)$ (specify type and grade of sarcoma) 
iii. Embryonal carcinoma

iv. Yolk sac tumor

v. Choriocarcinoma

$\alpha$. Variant- "monophasic" choriocarcinoma (7)

vi. Placental site trophoblastic tumor (7)

vii. Teratoma

$\alpha$. Mature

$\beta$. Immature

$\chi$. With a secondary malignant component ("teratoma with malignant transformation") (specify type)

1) Carcinoid

$\delta$. Monodermal variants

2) Primitive neuroectodermal tumor

3) Other

c. Tumors of more than one histologic type

i. Mixed germ cell tumor (specify components and provide an estimate of percent composition)

ii. Polyembryoma

iii. Diffuse embryoma (8)

d. "Burnt-out" germ cell tumor

2. Sex cord-stromal tumors

a. Leydig cell tumor (9)

b. Sertoli cell tumor

i. Not otherwise specified type (10)

ii. Large cell calcifying type (11)

iii. Sclerosing type

c. Sertoli-Leydig cell tumor (10)

d. Granulosa cell tumor

i. Adult type (13)

ii. Juvenile type (14)

e. Mixed sex cord-stromal tumor

f. Unclassified sex cord-stromal tumor

3. Mixed germ cell-sex cord-stromal tumors

a. Gonadoblastoma (15)

b. Others (16)

4. Miscellaneous

a. Lymphoma (classify according to guidelines for nodal lymphoma) (17)

b. Plasmacytoma and multiple myeloma

c. Granulocytic sarcoma and leukemic infiltrates

d. Sarcoma (specify type and grade)

e. Carcinomas and borderline tumors of ovarian-type (specify type and, for carcinomas, grade) (18)

f. Adenocarcinoma of the rete testis (19)

g. Adenocarcinoma of the epididymis

h. Melanotic neuroectodermal tumor (retinal anlage tumor) (20)

i. Malignant mesothelioma (specify type)

j. Desmoplastic small round cell tumor (21)

k. Others

5. Secondary tumors $(22,23)$

D. For tumors in the sex cord-stromal category (with the exception of the juvenile granulosa cell tumor) specify if adverse prognostic features are present or absent. The following are included $(9-11,13,24,25)$ :

1. Lymphovascular space invasion

2. Coagulative tumor cell necrosis

3. Significant cytologic atypia

4. "High" mitotic rate (specify number of mitotic figures per 10 high-power fields, averaged from 40 high-power fields)

5. Infiltrating borders 
6. Extra-testicular growth

a. Note: According to the revised TNM staging system of the American Joint Committee on Cancer,(26) only paratesticular soft tissue, tunica vaginalis, or spermatic cord involvement are features of extra-testicular spread that merit designation as pT2 tumors; cases with rete testis or epididymal spread or tunica albuginea invasion without penetration remain pT1 lesions in the absence of vascular invasion.

7. "Large" tumor size

E. For tumors in categories other than the sex cord-stromal group, specify if there is lymphovascular space invasion or (for testicular tumors) extra-testicular extension (see above-mentioned Note) (27-34)

F. Adequacy of local excision-assessment of resection margins

G. Other significant testicular disease

III. Features considered optional in the final report

A. Stage - the data specified should facilitate application of most staging systems. In most circumstances, the pathologist will not be aware of the nodal status or other studies to permit an assignment of stage; however, accurate local staging of the testicular tumor can be accomplished, either by providing all of the requisite information (as indicated above) or by specifying a local "P stage" according to the revised system of The American Joint Committee on Cancer Staging (26)

B. Results of ancillary studies

C. Association of germ-cell tumors with intratubular germ cell neoplasia of the unclassified type

D. Presence and type of inflammatory infiltrate

E. Multifocal tumor

\section{REFERENCES}

1. Nazeer T, Ro JY, Kee KH, Ayala AG. Spermatic cord contamination in testicular cancer. Mod Pathol 1996;9:762-6.

2. Mostofi FK, Sesterhenn IA. Histological typing of testis tumours. 2nd ed. Berlin: Springer-Verlag; 1998.

3. Ulbright TM, Amin MB, Young RH. Atlas of tumor pathology: Tumors of the testis, adenexa, spermatic cord and scrotum. Third series. Washington, D.C.: Armed Forces Institute of Pathology; 1999.

4. Hedinger C, von Hochstetter AR, Egloff B. Seminoma with syncytiotrophoblastic giant cells. A special form of seminoma. Virchows Arch A Pathol Anat Histol 1979;383:59-67.

5. Floyd C, Ayala AG, Logothetis CJ, Silva EG. Spermatocytic seminoma with associated sarcoma of the testis. Cancer 1988;61:409-14.

6. True LD, Otis CN, Delprado W, Scully RE, Rosai J. Spermatocytic seminoma of testis with sarcomatous transformation. A report of five cases. Am J Surg Pathol 1988;12:75-82.

7. Ulbright TM, Young RH, Scully RE. Trophoblastic tumors of the testis other than classic choriocarcinoma: "monophasic" choriocarcinoma and placental site trophoblastic tumor-a report of two cases. Am J Surg Pathol 1997;21:282-8.

8. de Peralta-Venturina MN, Ro JY, Ordonez NG, Ayala AG. Diffuse embryoma of the testis: an immunohistochemical study of two cases. Am J Clin Pathol 1994;101:402-5.

9. Kim I, Young RH, Scully RE. Leydig cell tumors of the testis. A clinicopathological analysis of 40 cases and review of the literature. Am J Surg Pathol 1985;9:177-92.

10. Young RH, Koelliker DD, Scully RE. Sertoli cell tumors of the testis, not otherwise specified: a clinicopathologic analysis of 60 cases. Am J Surg Pathol 1998;22:709-21.

11. Proppe KH, Scully RE. Large-cell calcifying Sertoli cell tumor of the testis. Am J Clin Pathol 1980;74:607-19.

12. Zukerberg LR, Young RH, Scully RE. Sclerosing Sertoli cell tumor of the testis: a report of 10 cases. Am J Surg Pathol 1991;15:829-34.
13. Jimenez-Quintero LP, Ro JY, Zavala-Pompa A, Amin MB, Tetu B, Ordonez NG, et al. Granulosa cell tumor of the adult testis: a clinicopathologic study of seven cases and a review of the literature. Hum Pathol 1993;24:1120-6.

14. Lawrence WD, Young RH, Scully RE. Juvenile granulosa cell tumor of the infantile testis. A report of 14 cases. Am J Surg Pathol 1985;9:87-94.

15. Scully RE. Gonadoblastoma. A review of 74 cases. Cancer 1970;25:1340-56.

16. Matoska J, Talerman A. Mixed germ cell-sex cord stroma tumor of the testis. A report with ultrastructural findings. Cancer 1989;64:2146-53.

17. Ferry JA, Harris NL, Young RH, Coen J, Zietman A, Scully RE. Malignant lymphoma of the testis, epididymis, and spermatic cord. A clinicopathologic study of 69 cases with immunophenotypic analysis. Am J Surg Pathol 1994;18:376-90.

18. Young RH, Scully RE. Testicular and paratesticular tumors and tumor-like lesions of ovarian common epithelial and mullerian types. A report of four cases and review of the literature. Am J Clin Pathol 1986;86:146-52.

19. Nochomovitz LE, Orenstein JM. Adenocarcinoma of the rete testis: consolidation and analysis of 31 reported cases with a review of miscellaneous entities. J Urol Pathol 1994;2:1-37.

20. Pettinato G, Manivel JC, d'Amore ES, Jaszcz W, Gorlin RJ. Melanotic neuroectodermal tumor of infancy. A reexamination of a histogenetic problem based on immunohistochemical, flow cytometric, and ultrastructural study of 10 cases. Am J Surg Pathol 1991;15:233-45.

21. Cummings OW, Ulbright TM, Young RH, Del Tos AP, Fletcher CD, Hull MT. Desmoplastic small round cell tumors of the para-testicular region: a report of six cases. Am J Surg Pathol 1997;21:219-25.

22. Haupt HM, Mann RB, Trump DL, Abeloff MD. Metastatic carcinoma involving the testis: clinical and pathologic distinction from primary testicular neoplasms. Cancer 1984;54: 709-14.

23. Tiltman AJ. Metastatic tumours in the testis. Histopathology 
I. Gross assessment of main tumor

1. Origin

Right testis

Left testis

Upper pole

Lower pole

Central

Diffuse

Paratestis

2. Extent

Hilum

Penetration of tunica albuginea

Epididymis

Paratesticular soft tissue

Spermatic cord

Scrotum

3. Dimensions

$\mathrm{cm} \times$

$\mathrm{cm} \times$ $\mathrm{cm}$

4. $\overline{\text { Extends }}$ to spermatic cord margin yes

II. Histologic information

1. Germ-cell tumor-one histologic type

a. IGCNU only

b. Other forms of intratubular germ-cell neoplasia (specify type)

c. Seminoma

with syncytiotrophoblasts

d. Spermatocytic seminoma

with sarcoma (specify type and grade)

e. Embryonal carcinoma

f. Yolk sac tumor

g. Choriocarcinoma

"monophasic" type

h. Placental site trophoblastic tumor

i. Teratoma

Mature

Immature

With a secondary malignant component (specify type)

Monodermal variants

Carcinoid

Primitive neuroectodermal tumor

Other (specify type)

2. Germ-cell tumor of more than one type

a. Mixed germ-cell tumor (specify components and estimate percent composition)

b. Polyembryoma

c. Diffuse embryoma

3. "Burnt-out" germ-cell tumor

4. Sex cord-stromal tumors

a. Leydig cell tumor

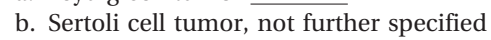

Large cell calcifying Sertoli cell tumor

Sclerosing Sertoli cell tumor

c. Sertoli-Leydig cell tumor

d. Granulosa cell tumor

Adult type

Juvenile type

e. Mixed sex-cord stromal tumor

f. Unclassified sex cord-stromal tumor

5. Mixed germ cell-sex cord stromal tumor

a. Gonadoblastoma

b. Other

6. Miscellaneous

a. Lymphoma (classify specifically)

b. Plasmacytoma or multiple myeloma

c. Granulocytic sarcoma or leukemic infiltrate

d. Sarcoma (specify type and grade)

e. Carcinoma of ovarian epithelial type (specify type and grade)

f. Borderline tumor of ovarian epithelial type (specify type)

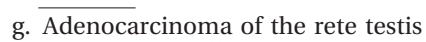

$\mathrm{h}$. Adenocarcinoma of the epididymis i. Melanotic neuroectodermal tumor (retinal anlage tumor)

j. $\overline{\text { Malignant mesothelioma (specify type) }}$

k. Desmoplastic small round cell tumor

l. Other (specify)

7. Secondary tumor (specify)

III. Additional histologic features for germ-cell tumors

1. Lymphovascular space invasion

Yes

No

2. Extra-testicular extension ${ }^{a}$

Yes

epididymis

tunica vaginalis

paratesticular soft tissue

spermatic cord

scrotum

No

3. Spermatic cord margin involved

Yes

No

IV. Additional histologic features for sex cord-stromal tumors

1. Lymphovascular space invasion

Yes

No

2. Necrosis

Yes

No

3. Significant cytologic atypia

Yes

No

4. Mitotic rate (specify no. of mitotic figures per 10 high power fields

5. Borders

Circumscribed

Infiltrating

6. Extra-testicular extension ${ }^{a}$

Yes

epididymis

tunica vaginalis

paratesticular soft tissue

spermatic cord

scrotum

No

7. Spermatic cord margin involved

Yes

No

V. Additional histologic features for categories other than germ-cell tumor or sex cord/stromal tumor

1. Lymphovascular space invasion

Yes

No

2. Extra-testicular extension ${ }^{a}$

Yes

epididymis

tunica vaginalis

paratesticular soft tissue

spermatic cord

scrotum

No

3. Spermatic cord margin involved

Yes

No

4. Other margins (parietal layer of tunica vaginalis, scrotum, etc.) involved

Yes (specify which)

No

VI. Special investigations

1. Flow cytometry

Yes

No

2. Other (specify type)

Yes

No

${ }^{a}$ Tumors involving rete testis, epididymis, and/or invading into (but not through) the tunica albuginea, in the absence of vascular invasion, are considered stage pT1. 
1979;3:31-7.

24. Jacobsen GK. Malignant Sertoli cell tumors of the testis. J Urol Pathol 1993;1:233-55.

25. Kratzer SS, Ulbright TM, Talerman A, Srigley JR, Roth LM, Wahle GR, et al. Large cell calcifying Sertoli cell tumor of the testis: contrasting features of six malignant and six benign tumors and a review of the literature. Am J Surg Pathol 1997;21:1271-80.

26. American Joint Committee on Cancer. Testis. In: Fleming ID, Cooper JS, Henson DE, Hutter RVP, Kennedy BJ, Murphy GP, et al. editors. AJCC cancer staging manual. Philadelphia: Lippincott-Raven; 1997. p. 225-30.

27. Dunphy CH, Ayala AG, Swanson DA, Ro JY, Logothetis C. Clinical stage I nonseminomatous and mixed germ cell tumors of the testis. A clinicopathologic study of 93 patients on a surveillance protocol after orchiectomy alone. Cancer 1988;62:1202-6.

28. Freedman LS, Parkinson MC, Jones WG, Oliver RT, Peckham MJ, Read G, et al. Histopathology in the prediction of relapse of patients with stage I testicular teratoma treated by orchidectomy alone. Lancet 1987;2:294-8.

29. Fung CY, Kalish LA, Brodsky GL, Richie JP, Garnick MB. Stage I nonseminomatous germ cell testicular tumor: prediction of metastatic potential by primary histopathology.
J Clin Oncol 1988;6:1467-73.

30. Jacobsen GK, Rorth M, Osterlind K, van der Maase H, Jacobsen A, Madsen EL, et al. Histopathological features in stage I non-seminomatous testicular germ cell tumours correlated to relapse. Danish Testicular Cancer Study Group. APMIS 1990;98:377-82.

31. Moul JW, McCarthy WF, Fernandez EB, Sesterhenn IA. Percentage of embryonal carcinoma and of vascular invasion predicts pathological stage in clinical stage I nonseminomatous testicular cancer. Cancer Res 1994;54:362-4.

32. Rodriguez PN, Hafez GR, Messing EM. Nonseminomatous germ cell tumor of the testicle: does extensive staging of the primary tumor predict the likelihood of metastatic disease? J Urol 1986;136:604-8.

33. Sesterhenn IA, Weiss RB, Mostofi FK, Stablein DM, Rowland RG, Falkson G, et al. Prognosis and other clinical correlates of pathologic review in stage I and II testicular carcinoma: a report from the Testicular Cancer Intergroup Study. J Clin Oncol 1992;10:69-78.

34. Wishnow KI, Johnson DE, Swanson DA, Tenney DM, Babaian RJ, Dunphy $\mathrm{CH}$, et al. Identifying patients with low-risk clinical stage I nonseminomatous testicular tumors who should be treated by surveillance. Urology 1989;34:339-43.

In the July, 2000, issue of Modern Pathology, the incorrect author was given credit for the book review of Koss LG, Gompel C: Introduction to Gynecologic Cytology with Histologic and Clinical Correlations (p. 741). The correct author of this review is Larry J. Fowler, University of Texas Health Science Center, San Antonio, Texas. We regret the error. 